\title{
Clarice Lispector: acontecimento, Deus e literatura.
}

\author{
Clarice Lispector: event, God and literature
}

\author{
Cicero Cunha Bezerra*
}

\begin{abstract}
Resumo
Este artigo tem como finalidade pensar, em diálogo com a hermenêutica espectral de John Caputo, especialmente no que se refere à experiência divina como acontecimento, a presença de Deus na obra de Clarice Lispector. Para tanto, nos deteremos em dois contos da autora buscando compreender em que medida literatura, acontecimento e Deus convergem em uma "experiência" de mundo que é, antes de tudo, irrupção desestabilizadora no âmbito da linguagem, mas, também, construção de uma narrativa que assume a palavra, paradoxalmente, como expressão e falência diante da irredutibilidade do acontecimento de Deus. Para tanto, dividiremos nosso trabalho em dois momentos. No primeiro, trataremos da relação entre acontecimento e mundo buscando expor, a partir da interpretação do conto Amor, publicado na obra Laços de Família, a relação entre acontecimento e cotidianidade. No segundo, analisaremos, a partir do conto Perdoando Deus, publicado em Felicidade Clandestina, o processo criativo clariciano em que, literatura, religião e Deus, dialogam mediante a distinção entre evento e acontecimento. À título de conclusão, buscamos evidenciar, a partir do diálogo com a hermenêutica radical de J. Caputo, elementos textuais, nos contos, que revelam um produtivo diálogo entre literatura, filosofia e teologia.
\end{abstract}

Palavras-Chaves: Acontecimento, Literatura, Clarice Lispector, John Caputo, Deus.

\begin{abstract}
This article aims to think, in dialogue with the spectral hermeneutics of John Caputo, especially regarding the divine experience as a event, the presence of God in Clarice Lispector's work. Thus, we'll dwell on two of hers short stories seeking to understand in which extent literature, event and God converge in an "experience" of the world that is, above all, destabilizing irruption in language, but also, construction of a narrative which assumes the word, paradoxically, as expression and collapse in the face of the irreducibility of God's event. In the first moment of the article, we'll deal with the relation between event and the world, seeking to expose, from the interpretation of the short story Love, from the book Family Ties, the relation between event and everyday life. Secondly, we'll analyze, from the short story Forgiving God, published in Clandestine Happiness, the Claricean creative process in which literature, religion and God dialogue through the distinction between event and happening. As a conclusion, we seek to evidenciate, from the dialogue with the radical hermeneutics of J. Caputo, textual elements, in the short stories, that reveal a productive dialogue between literature, philosophy and theology.
\end{abstract}

Key-words: Event, Literature, Clarice Lispector, John Caputo, God.

Artigo submetido em 12 de agosto de 2017 e aprovado em 15 de dezembro de 2017

* Graduação em Filosofia pela Universidade Federal do Rio Grande do Norte (1996), Mestrado em Filosofia pela Universidade Federal da Paraíba (1998) e Doutorado em Filosofia - Universidad de Salamanca (Espanha-2004). Atualmente é professor titular da Universidade Federal de Sergipe. Pesquisador do CNPQ/PQ2. País de Origem: Brasil. E-mail: cicerobezerra@hotmail.com

Horizonte, Belo Horizonte, v. 15, n. 48, p. 1504-1524, out./dez. 2017 - ISSN 2175-5841 


\section{Introdução}

Quero saber o que acontece quando não acontece nada. Qual é o oposto do acontecimento? Sei que não é "não acontecer". Acho que vem o indizível.

(LISPECTOR apud BORELLI, 1981, p. 37).

Gilles Deleuze, na sua obra Lógica do sentido define acontecimento com as seguintes palavras: "acontecimento tornado em si mesmo, esquiva todo presente, porque ele é livre das limitações de um estado de coisas, sendo impessoal e préindividual, neutro, nem geral nem particular, eventum tantum" (1974, p. 154). Esquiva não significa negação, mas, precisamente, afirmação da instantaneidade impessoal que, enquanto tal, permanece na efetuação e contra-efetuação do movimento de contração entre um ainda-futuro e um já-passado graças ao caráter de movimento que caracteriza o acontecimento como o que não se dá de modo estanque e redutível.

É precisamente esse aspecto de irredutibilidade, que marca o acontecimento, o que nos parece fundamental para se pensar, à luz da literatura de Clarice Lispector, em uma experiência imanente/transcendente do divino que, longe de esgotar-se na problemática substancialista ou transcendentalista de um Deus tomado como Ser, Ente ou, inclusive, Outro, abre para a possibilidade de incorporação de uma reflexão, clássica na história da filosofia e teologia, atualizando-a ao contexto pós-metafísico que demarca o pensamento contemporâneo.

Nessa perspectiva, a obra de Clarice Lispector dialoga, ainda que de modo indireto, com um contexto crítico filosófico-literário europeu que se define, sobretudo, por uma tônica na impossibilidade de um fundamento último capaz de justificar uma estrutura objetiva da realidade e, também, com uma longa tradição escriturária, tida como mística, que abarca grandes tradições e que encontra no solo judaico-cristão sua proximidade mais evidente. 
Olga Borelli (1981, p. 36), amiga pessoal de Clarice Lispector, após ressaltar a impossibilidade de se chegar a uma definição precisa das crenças religiosas de Clarice, afirma que o melhor testemunho do seu itinerário espiritual são seus textos. Sendo assim, seus textos, na grande maioria, irrompe como um epifenômeno que permite, por exemplo, uma crítica à linguagem bastante pessoal, ao modo desconstrucionista, que coloca em suspensão o(s) sentido(s) da linguagem e suas representações no que ser refere ao mundo, à vida, a Deus e à própria literatura $^{1}$ revelando uma filiação a um dos aspectos centrais da linguagem negativa ou apofática que consiste na constatação da sua própria falência como abertura a uma vivência possível do impossível, enquanto acontecimento de Deus no mundo.

Escrever como abertura para o im-possível acontecer de Deus é o que define a literatura como uma preensão persecutória ${ }^{2}$ que se mantém graças à sua insistente tarefa, quase peregrina, de construir sobre palavras o que escapa à toda nomeação. Misto de dor e alegria que remetem ao que Teresa D'Ávila nomeou de Moradas e que Clarice prefere chamar de "interior": "No meu interior encontro o silêncio procurado" (LISPECTOR, 1998, p. 69).

Silêncio que, enquanto metáfora, aponta para o que lhe escapa, a saber, a palavra e todos os seus usos e abusos. Pela fixação algo se depreende e flutua semelhantes às metáforas tão próprias às narrativas místicas. Elevar-se, com a consciência da des-possessão de tudo e de nada, inclusive da própria vontade, estágio último, mas primeiro, de todo êxtase. Participar ou comungar são metáforas mais próprias para definir o que, do ponto de vista racional, escapa a toda tentativa de descrição ou categorização conceitual. Há um hiato posto em todo ato. Essa intuição do abismo como espelho silencioso do céu, é, sem sombra de dúvida, o que faz da literatura clariciana uma interlocutora, também, de um certo logos filosófico-teológico pertencente a uma longa tradição que se espantou diante

\footnotetext{
${ }^{1}$ Sobre o tema ver: BEZERRA, 2015, p. 157-172.

2 Expressão que Maurice Blanchot utiliza para caracterizar a necessidade de escrever a partir de uma exigência imperiosa em que domínio (senhor da caneta) e dominação (senhoria das palavras) constituem o exercício da criação literária (2011, p. 16).
} 
do fato de que tudo o que é (ser) se dá como acontecimento (devir). Haveria, portanto, uma dinâmica relacional entre ser e devir.

No capítulo de John Caputo intitulado Hermenêutica espectral: sobre a debilidade de Deus e a teologia do acontecimento (2010, p. 74) encontramos uma interlocução, extremamente frutífera, que pode ser tomada como expressão para o tema aqui tratado. Segundo ele, acontecimento pode ser definido a partir de cinco aspectos que passamos a citá-los:

1. Acontecimento não é o que ocorre, mas algo dado no que ocorre, ou seja, não é algo presente, mas algo que busca dar-se no que está presente.

2. Em consequência do primeiro ponto, é necessário distinguir nome e acontecimento que está dando-se em um nome. Nesse sentido, nomear é sinônimo de uma formulação provisória de algo que se dá enquanto ocorre, acontece "a" e "para" alguém. Há, portanto, uma certa estabilidade na mutabilidade expressa nos inéditos modos dos acontecimentos. É quase impossível não pensarmos em uma luta entre o que acontece e a necessidade de nomear o que se dá em cada acontecer.

3. Em perfeita consonância com a ideia de uma diferença ontológica entre ser e ente, o acontecimento não é, segundo J. Caputo, uma coisa, mas algo que atua em uma coisa. Diz ele: "a inquietude do fluir das coisas se explica através dos acontecimentos que albergam" (CAPUTO, 2010, p. 76).

4. Outra consequência, que estrutura o quarto aspecto do acontecimento, reside no exercício de desconstrução de tudo que se refere ao acontecimento, menos o próprio acontecer que, enquanto tal não é desconstruível. Estamos na síntese entre presente e futuro.

5. Os acontecimentos nos convocam, nos provocam, nos promete (promessa), um por vir. Enquanto anúncio, o acontecimento interpela o indivíduo a um diálogo em que falar e calar são dois aspectos constitutivos de um ato de afecção corporal e anímico sob a forma de escrita solitária. 
Escrever implica, assim, em uma renúncia, em um esquecimento de si, em detrimento do ato de escrever. Ato que, enquanto tal, se constitui em um exigência que passa pela literatura e reconduz a ela. A literatura pode ser, assim, comparada à unidade que se faz múltipla e a um múltiplo que se faz uno, sem redução de um ao outro, mas exclusivamente, enquanto se dá, acontece, sob forma de narrativa.

Como, porém, pensar literatura, religião e acontecimento e Clarice Lispector? A princípio, devemos admitir que trata-se, obviamente, de um recorte bem delimitado. Insistimos, somente, em um aspecto interessante dessa nossa perspectiva que é o estabelecimento de uma ponte tripla entre a obra de Clarice a partir de três abordagens que convergem em três aspectos presentes na obra clariciana que são, respectivamente, filosóficas, teológica e a literária. Três vertentes transpassadas por uma mesma intuição que aponta para uma preocupação basilar última: a ruptura do silêncio diante da existência do mundo.

Acontecimento, no sentido deleuziano de devir, alinha-se, aqui, às ideias de J. Caputo baseadas na experiência de Deus nos acontecimentos que, por sua vez, dialoga de maneira direta com a ideia blanchotiana de literatura como acontecimento e por vir. Se, para Caputo, "na teologia pós-moderna o acontecimento outorga às coisas certo brilho divino - o divino nas coisas" (2010, p. 79), para Maurice Blanchot,

O caráter narrativo não é percebido quando nele se vê o relato verdadeiro de um acontecimento excepcional, que ocorreu e que alguém tenta contar. A narrativa não é o relato do acontecimento, mas o próprio acontecimento, o acesso a esse acontecimento, o lugar aonde ele é chamado para acontecer, acontecimento ainda por vir e cujo poder de atração permite que a narrativa possa esperar, também ela, realizar-se. (BLANCHOT, 2016, p. 8).

Narrativa como acontecimento que, enquanto tal, prepara, em sua dinamicidade, o espaço-texto como abertura para o por vir. Insistimos, uma vez mais, nesse aspecto de "abertura” como modo próprio, no caso das obras de Clarice aqui tratadas, tanto do processo de escrita, isto é, como momentos de eclosões que 
desencadeiam, na narrativa, experiências múltiplas, embora associadas a uma visão de unidade textual que, como já observamos, não se reduz a um único, mas a uma uniplurivocidade de acontecimentos, enquanto tematização de um evento primordial que se dá e se mantém como eixo central de elo entre os acontecimentos.

Metodologicamente, seguimos a indicação de Antonio Manzatto (1994), expressa em sua obra Teologia e literatura, quando o mesmo aponta, dentre outros caminhos, para um itinerário interpretativo que busca pensar conteúdos teológicos, presentes em textos literários, precisamente, enquanto literatura, isto é, como criação que, embora abram horizontes teológicos, não se aplicam, necessariamente, à teologia. Trata-se, portanto, de um encontro em que o teológico e o literário comungam e reelaboram-se.

Para esse nosso artigo, nos deteremos em dois contos, o primeiro, publicado originalmente em 1960 na obra Laços de família, se intitula Amor, o segundo, presente em Felicidade clandestina, publicado em 1971, se intitula Perdoando Deus. A escolha por esses dois contos tem como motivação, além das proximidades narrativas que os definem, algumas características comuns que esperamos evidenciar ao longo desse trabalho. Passemos para o primeiro conto.

\section{Acontecimento e mundo}

Um saco feito de tricô, uma mulher (Ana), um bonde, um cego. Figuras que tecem, na trama dos fios da linguagem clariciana, o enredo de um conto que tem o amor como tema. Viagem entre ruas margeadas por paradas que figuram como irrupções reveladoras de uma experiência de mundo que, somando às reflexões presente em romances como Um sopro de vida, assume o sentido mais profundo e radical de abismo. Fiel às preocupações existenciais calcadas na busca de uma estabilidade ou verdade que ampare a condição humana, Ana, personagem trânsito, como sua própria aventura, é descrita, no início do conto, como a mais 
corriqueira das pessoas que lutam, como lavradores, por construir um lar, uma família, uma vida que, enquanto tal, escapa-lhe, cresce e transborda sob forma de um movimento circular em que princípio, meio e fim são faces dinâmica de uma realidade que não se deixa abarcar ou dominar-se, pese a força e a necessidade humanas de conferir-lhe sentido e estabilidade.

Há sempre uma lacuna que revela, pelo silêncio que instaura, o risco inerente à existência. Quando nada mais precisava de sua força, inquietava-se (LISPECTOR, 2009, p. 19). Este sentimento, que pode ser tomado em seu aspecto de desassossego, revela mais do que perturbação. Nele, encontramos a expressão da condição conflitiva do ser humano face ao mundo que exige, sempre, no caso da obra de Clarice, superações. É importante sublinhar o plural aqui empregado. Não se trata de um superar que se dá em sua forma de completude, como algo realizável de todo, mas de um movimento de afirmação que congrega ilusão e realidade, mentira e verdade, dor e prazer, vida e morte, amor e ódio. “Todo o seu desejo vagamente artístico encaminhara-se há muito no sentido de tornar os dias realizados e belos; com o tempo seu gosto pelo decorativo se desenvolvera e suplantara a íntima desordem.” (LISPECTOR, 2009, p. 20).

Decorativo não significa superficial, mas possibilidade de transmutação, harmonização, diz o narrador: "Parecia ter descoberto que tudo era passível de aperfeiçoamento, a cada coisa se emprestaria uma aparência harmoniosa; a vida podia ser feita pela mão do homem" (LISPECTOR, 2009, p. 20). Como se pode constatar, decorar é criação que, no caso de Ana, tem o lar como modelo. Criação e verdade andam juntas. No confronto entre o antes e o depois do casamento de Ana, encontramos o significado para uma escolha que se consolida a partir da constatação de que a vida exige "raiz firme" (LISPECTOR, 2009, p. 20). Diríamos que Ana, no seu contínuo cuidado com as coisas, estabelece sentido, compreensibilidade e, também, firmeza. Marido, filhos, cortinas, camisas, comida, roupa cortada com tesoura afiada, revelam a persistência, continuidade e alegria de alguém que insiste na tarefa de ordenar os dias, as horas, os minutos, como se a 
vida exigisse uma atenção contínua e um ordenamento digno de "vida de adulto" (LISPECTOR, 2009, p. 20).

No entanto, paradoxalmente, quando tudo está arrumado, controlado, ordenado, é que, o cotidiano sempre escamoteia e escapa causando-lhe, a Ana, espanto. Na limpeza dos móveis reluz, para desespero da protagonista, sua dispensabilidade. “A casa estava vazia sem precisar mais dela” (2009, p. 20). Nesse momento, é preciso reagir, abafar esse sentimento dissociativo que, em último caso, revela a presença, sob imagem de espanto, da incompletude tanto da vida, quanto dos seus atos. Compras! Consertar objetos! Um ocupar-se com fim à espera. De quê? De quem? Do quê?

Ana, em sua trilha férrea, é corpo que se deixa, por escolha, "vacilar nos trilhos por entre ruas largas” (LISPECTOR, 2009, p. 21) para dar-se tempo ou, quiçá, para dar ao tempo, tempo e, então, regressar aos seus deveres, ou seja, dar tempo ao tempo na esperança de suplantar a sensação de que ao fim e ao cabo o que resta da sua lida e afazeres é a certeza de que o mundo tem "raízes negras e suaves” (LISPECTOR, 2009, p. 21). Negras em sua incomensurabilidade e suave em sua prazerosa transitoriedade. Semelhante a um maquinista, atento ao percurso, controlando a máquina na esperança de amanhã voltar aos mesmos trilhos, Ana opta por alimentar, a real ilusão de que o seu mundo segue, graças a sua resignação e aceitação, o ritmo normal dos dias.

Como, entretanto, a vida não tem trilhos certos, Ana é sacudida por um acontecimento: em uma parada de ônibus ela observa um cego que mastiga, imóvel, chiclete. Nada de extraordinário na cena, mas sem dúvida, a narrativa instaura, por sua força imagética, uma ruptura entre o ritmo dos acontecimentos que, por um átimo de segundo, se veem suspensos, e o estado de ânimo da protagonista. Ana é arrojada por um inquietante movimento que a tira de sua suposta tranquilidade momentânea e a coloca diante de uma verdade: o cego, ali parado, mascando chicles na escuridão, "não tinha sofrimento" (LISPECTOR, 2009, p. 21). 
É importante perceber que não se trata de um confronto entre Ana e o cego. Este último permanece passivo, exceto no ato de mascar chicles. É Ana que vê no "outro", que sequer lhe enxerga, os elementos necessários para a instauração de uma crise. Crise compreendida, conforme dissemos antes, como ruptura, transgressão de um suposto estado de segurança. Diríamos que o cego é uma porta aberta para a escuridão profunda da vida que Ana, em sua organização, tenta dublar, mas, semelhante a G.H., perde a muleta que lhe dava sustentação. O aparecimento do cego no conto, abre para uma nova experiência vivida pela protagonista que redefine os trilhos textuais da narrativa.

Se, na ocasião da sua aparição, o cego promovera um aparente "insulto" à protagonista, a ponto de quem a visse tivesse a impressão de ela estar com ódio (LISPECTOR, 2009, p. 22), após o estabelecimento da 'crise' o mundo passa a ser visto como um "mal-estar" (LISPECTOR, 2009, p. 22) promovido por um sem sentido, por uma "falta de lei" que faz com que a protagonista se agarre ao banco da frente do bonde. Espanto e prazer agora não mais passíveis de abafamento; o mundo que sempre esteve diante dos olhos de Ana, agora eclode entre ausência de piedade e vigor que a faz cair numa "bondade extremamente dolorosa" (LISPECTOR, 2009, p. 23).

Estamos diante do jogo instigante que Clarice Lispector sempre nos convida a adentrar, a olhar, ainda que de relance por meio dos seus personagens, para a vida em sua forma mais corriqueira e banal sem, com isso, perder de vista o caráter arrebatador dos acontecimentos simples. A desorientação reordena. Ana recuperada do susto e envolta em um morno e misterioso vento adormece dentro de si (LISPECTOR, 2009, p. 24) regulada, dessa vez, pelo silêncio do Jardim Botânico. Silêncio de um secreto trabalho que pouco a pouco Ana se dá conta. Ela está diante de uma fascinante vida que de tão vital causava-lhe náusea, nojo, misto de tremor e temor. O Jardim, como a barata em G.H., era digno de degustação3.

${ }^{3}$ Sobre a temática, especificamente, em A Paixão segundo G.H. ver: GROSS, 2010, p. 133-149, e BEZERRA, 2017, p. 57-73. 
Meio paraíso, meio inferno, o Jardim vivo em toda sua plenitude revelava a morte em tons de "mau ouro e escarlates" (LISPECTOR, 2009, p. 25).

A decomposição era profunda, perfumada... Mas todas as pesadas coisas, ela via com a cabeça rodada por um enxame de insetos, enviados pela vida mais fina do mundo. A brisa se insinuava entre as flores. Ana mais adivinhava que sentia o seu cheiro adocicado... O Jardim era tão bonito que ela teve medo do inferno (LISPECTOR, 2009, p. 25).

Uma vez mais, a experiência narrada vem marcada pela impessoalidade da protagonista. Ana não só viu o Jardim em sua plenitude, mas se fez Jardim, forma composta de seres, vida, beleza, nojo, pavor, liberdade. Diríamos que Ana vivenciou uma experiência extática que conjuga cegueira e visão. Não se pode esquecer, como o próprio texto revela, que foi o cego que guiou Ana até o Jardim. Só a culpa pôde romper esse estado de neutralidade em que se encontrava Ana. Ao lembrar das crianças em casa, Ana sente-se culpada e trata de voltar. Seu retorno é significativo e revelador. Ao deparar-se com o mundo brilhante das maçanetas, dos vidros, das janelas, das lâmpadas, se dá o reconhecimento catártico de um "modo moralmente louco de viver" (LISPECTOR, 2009, p. 26). Temos, com isso, dois aspectos da loucura expressos pela extrema ordem das coisas e pela complexa vida latente dos acontecimentos. Loucura dos homens e loucura de Deus? Essa bem que poderia ser uma pergunta a ser posta tomando como ponto de partida o contexto geral da obra clariciana em que mundo humano e mundo mundano se contrapõem na medida em que constituem uma mesma unidade.

Ana, conduzida pela cegueira é atingida pelo demônio da fé (LISPECTOR, 2009, p. 26). Fé como crença em um mundo que se revela em todo seu horror. A vida é horrível (LISPECTOR, 2009, p. 26). Horror como uma ostra, misto de desejo e nojo, dirá Ana. No entanto, o que parece horrível é doce, profundo, belo e isso a atrai e a ilumina invertendo os valores e exigindo um novo olhar sobre o seu cotidiano. O Jardim, que antes a espantou em sua força demoníaca, já não está fora, mas dentro de si e da cozinha. 
O pequeno horror da poeira ligando em fios a parte inferior do fogão, onde descobriu a pequena aranha. Carregando a jarra para mudar a água havia o horror da flor se entregando lânguida e asquerosa às suas mãos. $\mathrm{O}$ mesmo trabalho secreto se fazia ali na cozinha. (LISPECTOR, 2009, p. 28).

Secreto, não quer necessariamente dizer escondido, mas silencioso. A aranha tecia sua teia diariamente entre a ordenação do lar, mas agora, o que não aparecia se faz aparição, revelação de um tecer de uma vida silenciosa, lenta, insistente (LISPECTOR, 2009, p. 28). Fé. Mais uma vez essa palavra eclode no conto como um metrônomo que pontua o tempo de cada nota e simultaneamente sustenta o ritmo passageiro dos sons.

Com o mal, o amor se fez. Misto de piedade, compaixão e liberdade presa entre os “dedos". Na ânsia de possuí-la por mais que um instante, Ana ria-se de tudo (LISPECTOR, 2009, p. 28). O final do conto traz a seguinte questão: "o que o cego desencadeara caberia nos seus dias?” (LISPECTOR, 2009, p. 29). Cego e Jardim se entrelaçam e entre Ana e o mundo não há mais cisão, mas como toda experiência de unidade tende para a morte, seu corpo pede descanso. É hora de dormir e apagar a flama do dia (LISPECTOR, 2009, p. 29).

\section{Acontecimento e Deus}

Alberto Caeiro, em $O$ Guardador de Rebanhos, expõe uma cisão entre o pensamento e os sentidos das coisas. Diz ele: "Para mim pensar nisso é fechar os olhos. E não pensar" (PESSOA, 2005, p.23). Esse aspecto de "ignorância" que caracteriza, ao nosso ver, o poema de F. Pessoa intitulado Há bastante metafísica em não pensar em nada, no conto Perdoando Deus, de Clarice Lispector, sofre uma inversão radical, a saber, a ignorância, tratada como uma atenção sem esforço (1998, p. 41), que poderia ser associada ao "não pensar" de Caeiro, assume o sentido de uma compreensão de si como pré-condição para uma experiência metafísica das coisas bastante distinta do panteísmo lúcido apontado por Caeiro no poema acima citado. O mistério, para Clarice, não é que haja alguém que pense no 
mistério das coisas, como diz Caeiro, mas que entre esse alguém e as coisas haja sempre "algo" que interpela e convoca o ser humano e que, enquanto tal, escapa a toda compreensão e modo de representação.

O conto está estruturado em três momentos, intercalados por um acontecimento. Sigamos a narrativa. Na abertura, temos a descrição da liberdade como estado de ânimo em que se encontra a protagonista: "Eu ia andando pela avenida Copacabana e olhava distraída edifícios, nesga de mar, pessoas, sem pensar em nada. Ainda não percebera que na verdade não estava distraída, estava era de uma atenção sem esforço, estava sendo uma coisa muito rara: livre. (LISPECTOR, 1998b, p. 41).

Distração, não pensamento e atenção sem esforço apontam para um certo desprendimento e satisfação comparados, no conto, como sentir-se, maternalmente, “mãe de Deus” (LISPECTOR, 1998b, p. 41). No entanto, esse estado de passividade e entrega sofre paulatinamente uma alteração e é introduzida a ideia de percepção. "Pouco a pouco é que fui percebendo que estava percebendo as coisas” (LISPECTOR, 1998b, p. 41). Percepção conduz, na narrativa, a um aumento de liberdade. Como se a protagonista passasse, ao perceber que não se tratava de uma distração, para uma compreensão de um olhar que, enquanto tal, liberta o indivíduo dos laços categóricos que norteiam o pensamento e as coisas. Essa afirmação pode ser atestada na constatação de não pertencimento, ou melhor, de não alienação, entre a protagonista e o mundo em volta: "Não era tour de propriétaire, nada daquilo era meu, nem eu queria. Mas parece-me que me sentia satisfeita com o que via” (LISPECTOR, 1998b, p. 41).

É preciso observar que Deus, terra e mundo, são descritos, nesse momento, como sinônimos e que essa "satisfação" se dá como um "sentimento por puro carinho" (LISPECTOR, 1998b, p. 41). Trata-se, assim, de um estado emocional vivenciado pela protagonista que percebe e se percebe como unidade (Indivíduo- 
Deus-Mundo). No entanto, esse clímax é quebrado por um acontecimento:“foi quando quase pisei num enorme rato morto” (LISPECTOR, 1998b, p. 42).

$\mathrm{O}$ que antes era paz e sossego se transforma em terror e horror. $\mathrm{Na}$ instantaneidade de um acontecimento o medo cega a visão. Em um átimo toda paz se converte em violência. Sentimento infantil se presentifica em grito profundo. "Mas a imagem colava-se às pálpebras: um grande rato ruivo, de cauda enorme, com os pés esmagados e morto, quieto, ruivo. O meu medo desmensurado de ratos.” (LISPECTOR, 1998b, p. 42).

Dois atos pontuam esse acontecimento. O primeiro, após a perplexidade diante da "violência" que o acontecimento lhe causou, foi tentar desvincular os fatos. Essa tentativa de não associar paz e o horror revela, por parte da protagonista, por um lado sua "parcial" visão de que o mundo possui uma lógica unilateral e, por outro, a insuficiência de compreensão do sentido do mundo. Sentido que se revela, precisamente, pela ilogicidade do nexo negado entre os fatos.

O segundo, consistiu em voltar-se para o seu objeto de amor (Deus) e questioná-lo quanto à validade dos sentimentos a ele dirigido. Por que Deus faria tamanha agressão com alguém que o ama desinteressadamente? Por que jogar em sua cara o sangue? É interessante observar como a protagonista, em uma espécie de diálogo consigo, busca reestruturar-se diante do pânico sofrido:

De que estava Deus querendo me lembrar? Não sou pessoa que precise ser lembrada de que dentro de tudo há sangue. Não só não esqueço o sangue de dentro como eu o admito e o quero, sou demais o sangue para esquecer o sangue, e para mim a palavra espiritual não tem sentido, e nem a palavra terrena tem sentido (LISPECTOR, 1998b, p. 42).

Estaria Deus colocando à prova o amor da protagonista? Sua atitude, imediata, diante do que é tomado como um "insulto", por parte de Deus, é vingança. Mas como vigar-se de um Deus que não se deixa sequer encará-lo? Que por uma ação tão banal quanto um rato morto, reduziria o indivíduo à 
vulnerabilidade de criatura? É nesse momento da narrativa que encontramos uma das características mais marcantes da literatura clariciana e do que nomeamos, na esteira do pensamento de John Caputo, acontecer literário.

Se, para Caputo, não é o evento em si mesmo, mas o que desencadeia-se no evento, enquanto o que acontece, o que outorga às coisas o brilho divino, seria possível dizer que a escrita clariciana é, fundamentalmente, uma escrita do acontecimento de Deus e manifestação contínua do desejo incessante, pela criação literária, do incondicional4 sob o ato de nomeação.

Um dos pontos centrais de uma teologia 'fraca' ou de uma hermenêutica radical, como postula Caputo, consiste em pensá-la sempre como interpelação frente a audácia e persistência em afirmar a existência de Deus como um apelo ao impossível e ao audacioso. É, precisamente, nesse aspecto de um querer, baseado, paradoxalmente, no reconhecimento da não existência Deus, não como negação simplesmente, mas como aposta, que encontramos um paralelo com a obra de Clarice. Diz Clarice respondendo a uma provocação da sua amiga Olga Borelli, ao ser indagada sobre o "querer acreditar": "Só me enganando que existe Deus é que consigo viver. Se não fosse a fé inexplicável pelo Desconhecido, o desespero me destruiria. Eu finjo que existe 'Deus' para aguentar o inexplicável através do inexplicável.” (BORELLI, 1981, p. 36).

Fingimento diante de algo afirmado como “inexplicável”. Essa ideia da negação da existência de Deus como condição para o próprio ato de acreditar pode ser pensada, à luz do pensamento de J. Caputo, com o caráter de "ateísmo obrigatório" que reside em cada afirmação de Deus. Diz Caputo: "Se tudo que existe é desconstruível, então o acontecimento, que não é desconstruível, está,

\footnotetext{
${ }^{4} \mathrm{O}$ termo incondicional refere-se ao elemento presente em qualquer experiência religiosa responsável pelo caráter religioso dessa experiência. Todos os símbolos religiosos do divino expressam certa afirmação incondicional [...]. Não se trata de um ser, mas de uma qualidade. Caracteriza nossa preocupação suprema e, consequentemente, incondicional, não importando se a chamarmos de 'Deus', de 'ser', do 'bem', da 'verdade', ou de qualquer outro nome. Incorreríamos em crasso erro se entendêssemos o incondicional como um ser cuja existência pudesse ser discutida. Só falará a respeito da 'existência do incondicional' quem não entender o sentido do termo. Trata-se da qualidade experimentada no encontro com a realidade, por exemplo, no caráter incondicional da voz da consciência, tanto lógica quanto moral". Cf. TILLICH, 1992, p. 63.
} 
justamente, além do alcançável nos limites do que existe” (CAPUTO, 2010, p. 91). Mundo e Deus são expressões da irredutibilidade da vida em sua acontecência.

“Do que estava Deus querendo me lembrar?” (LISPECTOR, 1998b, p. 42), essa pergunta que ecoa como advertência e que, no conto, é rechaçada, em princípio, com uma negativa "não sou pessoa que precise ser lembrada", abre para uma possibilidade conciliadora entre o "Deus bruto" e a entrega amorosa da personagem:

mas quem sabe, foi porque o mundo também é rato, e eu tinha pensado que já estava pronta para o rato também. Porque eu me imaginava mais forte. Porque eu fazia do amor um cálculo matemático errado: pensava que, somando as compreensões, eu amava. (LISPECTOR, 1998b, p. 43).

Como já ressaltamos, Deus, mundo e terra são sinônimos e, nesse sentido, a imagem do rato morto faz com que a personagem perceba que é pela soma das incompreensões, e não das compreensões, que se ama verdadeiramente a Deus. Estamos tratando de algo muito próximo daquilo que Nicolau de Cusa, em seu $D e$ visione Dei, chamou de Douta ignorância, isto é, uma experiência limite que, nas palavras de João Maria André, pode ser definida como o que permite reconhecer o "caráter conjectural de qualquer formulação e definir o processo cognoscitivo pela sua dimensão progressiva e inconclusa” (1988, p. 89).

Chegamos assim a uma relação importante envolvendo desejo, acontecimento e Deus. Desejo, no conto, é o amor que se apresenta, em um primeiro momento, como querer amar o que se quer amar. Nesse querer o que se quer, voltamos à temática da relação (mediação) entre o ser humano e Deus. Em perfeita consonância com o pensamento de Mestre Eckhart, em seu Sermão 5b intitulado In hoc apparuit caritas dei in nobis 5 , Clarice Lispector aponta para o limite que, enquanto tal, é abertura do humano para Deus, a saber: a necessidade de desvinculação, não dos acontecimentos, mas da redução do que acontece aos

\footnotetext{
${ }^{5}$ Uma das tônicas do pensamento eckhartiano consiste em pensarmos Deus como "sem modo" e, consequentemente, a relação entre Deus e alma passa, necessariamente, pela superação de todo modo. Diz ele: "Pois quem busca a Deus em um <determinado> modo, toma o modo e perde Deus, que está oculto no modo. Cf. ECKHART, 2006, p. 67.
} 
fatos. Em uma das afirmações mais desconcertantes do conto, lemos: "É porque só poderei ser mãe das coisas quando puder pegar um rato na mão. Sei que nunca poderei pegar num rato sem morrer de minha pior morte" (LISPECTOR, 1998b, p. 44).

Dupla morte como suspensão entre a simplicidade, expressa pelo magnificat, entoado ao que não se ver, e o formalismo que contém a alma, ao mesmo tempo em que a protege nos limites da inocência. $\mathrm{O}$ amor a Deus não pode ser, segundo a narrativa clariciana, uma atribuição valorativa a um oposto, no sentido de que Deus é bom, porque eu sou ruim (LISPECTOR, 1998b, p. 45). Nessa relação o que permanece como vínculo é a projeção modal de um amor que busca, paradoxalmente, no Outro, amar-se a si mesmo. Teimosia e possessão, figuram como expressões de uma tentativa de redução do acontecimento à estabilidade de um cotidiano que exclui o devir, o inesperado e o escândalo como expressões de um Deus que escapa a toda tentativa de redução e aprisionamento. "Enquanto eu inventar Deus, Ele não existe" (LISPECTOR, 1998b, p. 45).

Vale ressaltar que "não existência" é tomada como oposição à ideia de fato consumado e, nesse sentido, Deus não se dá como fato, mas os fatos, enquanto acontecem, revelam o que não se deixa conter. Assumimos, portanto, a noção de religião dada por John Caputo como uma ideia que abarca bem o que poderia ser uma experiência religiosa presente na obra de Clarice, a saber: "Religião significa fazer a acontecer Deus no mundo e fazermo-nos dignos do que acontece" (CAPUTO, 2010, p. 105). No caso de Clarice, e restringindo-nos ao aspecto da criação literária, religião, acontecimento e literatura estão, portanto, intimamente ligadas. A literatura alberga e instaura o acontecer divino, mantendo-o sempre livre das palavras que não o contém. 


\section{Considerações finais}

Após analisarmos os contos, como aproximações à ideia de acontecimento, associando-a a uma experiência de Deus que se caracteriza, precisamente, por sua irredutibilidade aos fatos, cumpre retirarmos algumas conclusões sobre as relações possíveis entre a literatura clariciana e a teologia do acontecimento, particularmente, presente na texto Hermeneutica espectral de John Caputo. Um dos aspectos centrais do pensamento hermenêutico assumido por Caputo, diz respeito à associação da teologia do acontecimento a uma interpretação alternativa do evento fundador da narrativa judaica do Gênesis.

Segunda essa, Elohim não teria criado as coisas ex nihilum, interpretação comum à tradição metafísica ocidental, mas adornado, iluminado o que era escuro e sem vida (CAPUTO, 2010, p. 79). A palavra como um despertar das coisas adormecidas ou um acontecer de Deus, tomado justamente como teologia por Caputo, isto é, como um discurso que revela o que se dá no ato de nomear, mas que, enquanto nomeação, instaura a tensão inquietante entre as palavras e as coisas (CAPUTO, 2010, p. 81), encontra, na literatura de Clarice, uma interlocução criativa e que, do ponto de vista da aparição de Deus na obra, torna-se elo de ligação entre os elementos que poderíamos nomeá-los de religiosos ou espirituais e que remontam, de modo geral, às tradições judaicas e cristãs, e o presente, como revisão da experiência humana diante de um Deus que permanece como temor $e$ tremor. Estremecimento ou escândalo como diz a protagonista em Perdoando Deus.

É certo que a literatura de Clarice Lispector não postula, de modo direto, nenhuma perspectiva teológica, nem muito menos se insere em um contexto de crítica ou superação de concepções teóricas sobre Deus, o que não inviabiliza uma filiação, enquanto vizinhança, por certo de difícil delimitação, mas com pistas, bastante expressivas, a autores como Espinosa, Nietzsche e Dostoievski e, por vias 
diversas, a alguns autores da tradição mística cristã ${ }^{6}$. No entanto, estamos convencidos de que, assim como observou Marina Colasanti à própria Clarice7, o trabalho dela seria "de dentro para fora e não de fora para dentro" (2005, p. 152). Clarice chega a brincar em tom descontraído com o seu processo de criação. Algo como deixar-se tomar pelas coisas e ideias. "Estou sentada numa cadeira e fico. Nem eu mesma sei que estou fazendo alguma coisa. De repente vem uma frase...” (LISPECTOR, 2005, p. 150).

É nesse solo comum de desconstrução das categorias lógicas, quando aplicadas a Deus, que podemos enxergar uma hermenêutica espectral que substitui o "amor fati" pelo "amor venturi" (CAPUTO, 2010, p. 82) e que reúne teologia, filosofia e literatura em torno de uma compreensão da vida como nascimento e criação de sentido, mantendo, tanto as palavras quanto as coisas, livres e inseridas em uma superfície sagrada carregada de centelha divina (CAPUTO, 2010, p. 83).

Na descrição de Caputo, o acontecimento, longe de ser reduzido ao factual, resiste a toda contração e forma finita e, em sendo assim, implica em um movimento de desconstrução que abre, no que ocorre, para o porvir. É a literatura clariciana uma abertura para o acontecimento e o povir? Vejamos essa caracterização de acontecimento dada por Caputo:

A verdade eterna do acontecimento é seu nomadismo, sua viagem inacabável através de oceanos desconhecidos e, sem dúvida, seu descontento com as formações mais sedimentadas e sedentárias - se bem que as antigas crenças nos dizem que uma característica do nômade é sua hospitalidade [...]. (CAPUTO, 2010, p. 89).

Para o teólogo, a teologia é o lugar para o cultivo e liberação do acontecimento. Hospitalidade, acolhimento e abertura são, na literatura clariciana, sinônimos de uma escrita que alberga o mistério e o milagre das coisas que só são

\footnotetext{
${ }^{6}$ Autores como Benedito Nunes (1966) e Regina Pontieri (1999) estabelecem conexões interessantes entre, por exemplo, a literatura de Clarice e obras de Teresa D’Ávila e, de modo geral, com a tradição apofática cristã, em especial, com Dionísio Pseudo-Areopagita e Mestre Eckhart. Sobre o tema ver: BEZERRA, 2015, p. 157-172.

${ }^{7}$ Marina Colasanti participa como interlocutora no Depoimento de Clarice Lispector gravado em 20 de outubro de 1976 no Museu da Imagem e do Som do Rio de Janeiro. Texto publicado na coletânea LISPECTOR, C. Outros escritos (2005, p.137-171).
} 
compreendidos pela não compreensão desestruturante que instaura o âmbito do pré-compreensivo que tem, centralmente, no amor seu princípio e fim. Em Água viva lemos: "estou atrás do que fica atrás do pensamento" (LISPECTOR, 1998a, p.12). Caputo afirma que a "literatura e a teologia são lugares onde sonhamos com o que está por vir" (2010, p. 91). É nesse sentido que compreendemos as inquietações e provocações de passagens de Água Viva como : "Há uma linha de aço atravessando isto tudo que te escrevo. Há o futuro. Que é hoje mesmo" (LISPECTOR, 1998a, p. 35).

Futuro-hoje que, enquanto "trevas de um passado remoto" (LISPECTOR, 1998a, p. 35), também é por vir e presságio de um Deus que se dá, eroticamente, em tudo que é vivo, mas que permanece como deserto e ausência. A literatura, assim como a teologia, exige e se dá como criação, ou como nos diz J. Derrida (2006, p. 93), invenção que faz acontecer o que ainda não está. Tanto para Clarice Lispector como para J. Caputo, Deus permanece como loucura divina que, enquanto tal, faz do mundo moradas de uma anarquia sagrada ${ }^{8}$, desestruturante, provocadora e libertária.

\section{REFERÊNCIAS}

BATTELLA, N. G. Clarice, uma vida que se conta. São Paulo: Ática, 1995.

BEZERRA, C. C. Clarice Lispector: escrever para se livrar de si. O eixo e a roda: revista de literatura brasileira, Belo Horizonte, v. 24, n. 2, p. 157-172, 2015.

BEZERRA, C.C. Clarice Lispector e as fronteiras do Nada: ensaio sobre filosofia e literatura. O eixo e a roda: revista de literatura brasileira, Belo Horizonte, v. 26, n. 3, p. 57-73, 2017.

BLANCHOT, M. O espaço literário. Tradução de Álvaro Cabral. Rio de Janeiro: Rocco, 2011.

\footnotetext{
${ }^{8}$ John Caputo define o Reino de Deus como "anarquia sagrada" que se expressa nas inversões de princípios e ordem. Um Reino em que a sabedoria não é dos virtuosos ou sábios, mas das prostitutas. Um Reino no qual é possível odiar pai e mãe e amar a um inimigo etc. Cf. 2010, p.98-99.
} 
BLANCHOT, M. O livro do Por Vir, tradução Leyla Perrone-Moisés. São Paulo: Martins Fontes, 2016.

BORELLI, O. Clarice Lispector, esboço para um possível retrato. Rio de Janeiro: Nova Fronteira, 1981.

BOSI, A. Céu, Inferno. São Paulo: Ática, 1988.

CAPUTO, J. Hermenéutica espectral: sobre la debilidad de Dios y la teología del acontecimiento in: VATTIMO, G.; CAPUTO, J. Después de la muerte de Dios, conversaciones sobre religión, política y cultura. Tradução de Antonio José Antón. Buenos Aires: Paidós, 2010. p. 75-134.

CAPUTO, J. La debilidade de Dios, una teología del acontecimiento. Tradução de Raul Zegarra. Buenos Aires: Prometeo Libros, 2014.

CAPUTO, J. The Return of Anti-Religion: From Radical Atheism to Radical Theology. Journal for Cultural and Religious Theory, Denver, v. 11, n. 2, p. 32-125, 2011.

CERTEAU, M. A invenção do cotidiano. Tradução de Epharaim F. Alves. Petrópolis: Vozes, 2011. v. 1.

COLIN-B.C. John Caputo: faiblesse de Dieu et déconstruction de la théologie. Montpellier: Institut Protestant de Théologie, 2015.

CUSA, A douta ignorância. Tradução, introdução e notas de João Maria André. Lisboa: Calouste Gulbenkian, 2008.

DELEUZE, G. Lógica do sentido. Tradução de Luiz Roberto Salinas Fortes. São Paulo: Perspectiva, 1974.

DERRIDA, J. SUSSANA, G. NOUSS, A. Decir el acontecimento ¿es posible? Tradução de Julián Santos Guerrero. Madrid: Arena Libros, 2006.

ECKHART, M. Sermões alemães. Tradução de Enio Paulo Giachini. Petrópolis: Vozes, 2006.

GROSS, E. A Busca do Ser e o Encontro do Nada em “A Paixão Segundo G.H.” de Clarice Lispector. Numen: revista de estudos e pesquisa da religião, Juiz de Fora, v. 11, n. 1 e 2, p. 133-149, 2010.

LISPECTOR, C. Água viva. Rio de Janeiro: Rocco, 1998a.

LISPECTOR, C. Felicidade clandestina. Rio de Janeiro: Rocco, 1998b.

LISPECTOR, C. Laços de família. Rio de Janeiro: Rocco, 2009.

LISPECTOR, C. Outros escritos. Rio de Janeiro: Rocco, 2005. 
LISPECTOR, C. Todos os contos. Rio de Janeiro: Rocco, 2016.

MANZATTO, A. Teologia e literatura. São Paulo: Loyola, 1994.

MOISÉS, M. Dicionário de termos literários. 12. ed. São Paulo: Cultrix, 2004.

NUNES, B. O mundo de Clarice, Manaus: Edições Governo do Estado do Amazonas, 1966.

PESSOA, F. Poesia completa de Alberto Caeiro. Edição Fernando Cabral Martins, Richard Zenith. São Paulo: Companhia das Letras, 2005.

PONTIERI, R. Clarice Lispector, uma poética do olhar. São Paulo: Ateliê editorial, 1999

TILliCH, P. Kairos. In: TILliCH, P. A Era Protestante. Tradução de Jaci Maraschin. São Paulo: ASTE, 1992.

VATTIMO, G. CAPUTO, J. Después de la muerte de Dios, conversaciones sobre religión, política y cultura. Tradução de Antonio José Antón. Buenos Aires: Paidós, 2010. 